\title{
Felkért hozzászólás \\ „Michéli Erika, Fuchs Márta, Szegi Tamás, Csorba Ádám, Dobos \\ Endre, Szabóné Kele Gabriella: A diagnosztikus szemléletben megújított hazai talajosztályozási rendszer: alapelvek, felépítés, osztályozási szabályok" \\ című vitaanyagához (2018.10.10.) „,erdész” szemmel
}

BIDLÓ András

Soproni Egyetem, Erdőmérnöki Kar, Környezet- és Földtudományi Intézet

(Beérkezett: 2019.11.18.; Elfogadva: 2019.11.19.)

\section{Bevezető gondolatok}

Egy talajosztályozási rendszer létrehozásakor, illetve értékelésekor az első kérdés, amit fel kell tennünk maguknak, hogy mi a rendszer célja, illetve mire szeretnénk a rendszert használni. A szerzők (MICHÉLI et. al, 2018) javaslatukban maguk is hangsúlyozzák, hogy a talajosztályozási rendszerek „Rendszerezik a talajokról szerzett tudásunkat, összefüggéseket fogalmaznak meg, biztosítják azok összehangolt értelmezését és nem utolsó sorban információt szolgáltatnak a talajt használóknak, a döntéshozóknak, a társtudományoknak és az egész társadalomnak." Ezzel jelen szerző is teljesen egyetért, ugyanakkor érdemes tisztázni, hogy mi lehet a társadalom, a használók és a döntéshozók elvárása egy rendszerrel szemben. Épp ezért véleményemet „erdész” szemmel igyekeztem elkészíteni, azaz magamnak kettős kérdést tettem fel. Egyrészt miként használható az új rendszer a gyakorlati talajosztályozás során, másrészt miként illeszthető be és alkalmazható az új rendszer a jelenleg használatos erdészeti termőhelyosztályozási rendszerbe, illetve milyen többlet információkat ad / adhat az új rendszer a korábbiakhoz képest, illetve esetleg milyen információk vesznek el használata során.

Mivel egy új, még kialakuló rendszerről van szó, előre kell bocsátanom, hogy az új rendszer használatában nincs megfelelö jártasságom, illetve gyakorlatom. Ennek megfelelően véleményemet elsősorban egy szakmai vita részeként kérem kezelni, amely vitának az a célja, hogy hazánkban minél szélesebb körben és a felhasználók által egyértelmüen használható talajosztályozási rendszer jöjjön létre.

\section{A megújítás szükségessége}

A szerzők (MichÉLI et. al, 2018) alapvetően három okkal magyarázzák a megújítás szükségességét. Egyrészt az új, nagy mennyiségü adat rendelkezésre állásával, illetve ezek digitális feldolgozási lehetőségével, másrészt azzal, hogy a nemzetközi rendszerek „az egyértelmü definiciókon és számszerü határértékeken

Levelezö szerző: BIDLÓ ANDRÁs, Soproni Egyetem, Erdőmérnöki Kar, Környezet- és Földtudományi Intézet, 9400 Sopron, Bajcsy-Zsilinszky u. 4.

E-mail: bidlo.andras@uni-sopron.hu 
nyugvó, úgynevezett diagnosztikus szemléleten alapulnak", harmadrészt azzal, hogy „az osztályozás leiró jellegü meghatározásai és döntési szabályai sok szubjektív elemet tartalmaznak, amelyek megnehezítik a talajok egyértelmü elkülönitését, elnevezését és nemzetközi megfeleltetését". Egyet kell érteni azzal, hogy a jelenleg használt magyarországi talajosztályozási rendszerek sok szubjektív elemet tartalmaznak, ráadásul egymástól jelentősen különböznek. Utóbbira elég egy egyszerü példa. Ha megnézünk három az utóbbi időben megjelent kiadványt, akkor a következőket tapasztalhatjuk. STEFANOviTs et. al. (1999) talajtanában $39 \mathrm{db}$, DÖVÉNYI (szerk) (2010) munkájában $31 \mathrm{db}$ és az erdészeti termőhelyosztályozásban (ÁESZ, 2004) 44 db genetikai talajtípus kerül felsorolásra. Ennek megfelelően nem biztos, hogy egy agráros, egy földrajzos és egy erdész azonos „nyelven” beszél. Egyet kell értenünk a javaslat kidolgozóival, hogy egyértelmü definíciókon és határértékeken alapuló rendszer szükséges, amely lehetővé teszi az adatok digitális feldolgozását. Ennek az elvárásnak a javaslat megfelel, ugyanakkor a cél elérése érdekében nem biztos, hogy az új rendszer az egyetlen lehetőség.

\section{A megújított rendszer felépítése}

A javaslat 15 talajtípust határoz meg, amelyek részben megfeleltethetők a nemzetközi rendszereknek, de a hazai tapasztalatok alapján új talajtípusok is bekerültek a rendszerbe. A talajtípusok megőrzése kedvező, ugyanakkor az eddigi típusok számának drasztikus csökkentése azt is jelenti, hogy egymástól sokban különbözö talajok is azonos típusba kerülnek. További osztályozási egységet jelentenek az altípusok és a változatok. Ebben az esetben már a jelenlegitől érdemben eltérő tulajdonságok alapján is elkülöníthetők a talajok.

\section{Az osztályozás adatigénye}

Az egyes típusok, altípusok és változatok elkülönítése diagnosztikai jellemzők alapján történik. A megadott terepi és laboratóriumi adatok nagy része jól ismert. Ugyanakkor több olyan paraméter van (pl. tömődöttség, porozitás, plaszticitás, ragadósság) amely pontos meghatározása a terepen nehézségbe, bizonytalanságba ütközik. A laboratóriumi adatok olyan vizsgálatok (pl. kationcserekapacitás, bázistelítettség, kicserélhető kationok $(\mathrm{Na}, \mathrm{K}, \mathrm{Mg}, \mathrm{K})$, elektromos vezetőképesség (EC), ODOE érték) elvégzését is igénylik, amelyek a gyakorlati talajtanban ritkák. A fentiek azt jelentik, hogy a javasolt rendszer adatigénye lényegesen meghaladja a jelenleg alkalmazott osztályozás adatigényét, ezek nélkül az egyes típusok és változatok „objektív” elkülönítése nem lehetséges. Véleményem szerint, már ez a jelentős többlet adatigény is megnehezítheti az új rendszer bevezetését, illetve a korábbi osztályozási rendszer adatainak konvertálását, hiszen a legtöbb talajleírás nem tartalmaz a TIM-hez hasonló részletességü terepi és laboratóriumi adatokat. 


\section{Néhány megjegyzés az egyes talajtípusokhoz}

Láptalajok

$\mathrm{Az}$ új rendszerben legalább $40 \mathrm{~cm}$ vastag és legalább $20 \%$ szerves szenet tartalmazó szinttel kell rendelkezniük az ilyen talajoknak. A korábbi rendszerben nem volt vastagsági határ és a szerves széntartalom határértéke $10 \%$ volt. Ennek megfelelően a kotus láptalajok egy része és a sekély (pl. lebomlott) láptalajok nem fognak ide tartozni. A láptalajok kiterjedése csökkeni fog.

\section{Antropogén talajok}

$\mathrm{Az}$ új rendszer egyik előnye a típus megjelenése, hiszen ilyen típust tudomásom szerint - eddig csak a hazai erdészeti talajosztályozás különített el. Ugyanakkor a típus meghatározása részben nagyon tág (,A szántás, forgatás mélysége eléri vagy meghaladja az 50 cm-t”). Mivel az erdő, gyümölcsös és szőlő telepítése során gyakran alkalmaznak mélyszántást, az ilyen jellegü területek (pl. a Duna-Tisza közének humuszos homokon található erdők nagy része) ebbe a kategóriába fog esni. Ezt nem tartom szerencsésnek. Ugyanakkor számomra nem egyértelmü, hogy a meddőhányók is ebbe a típusba tartoznak-e, hiszen azok talajanyaga nem „ember által létrehozott”. Ezt pontosítani kell.

\section{Köves-sziklás váztalajok}

A talajtípus definíciója nagyjából megegyezik a jelenlegivel. Érdemes lenne altípusként, vagy változatként a kőzet aprózódásának mértékét is jelezni (Pl. sekélyen, mélyen felaprózódott).

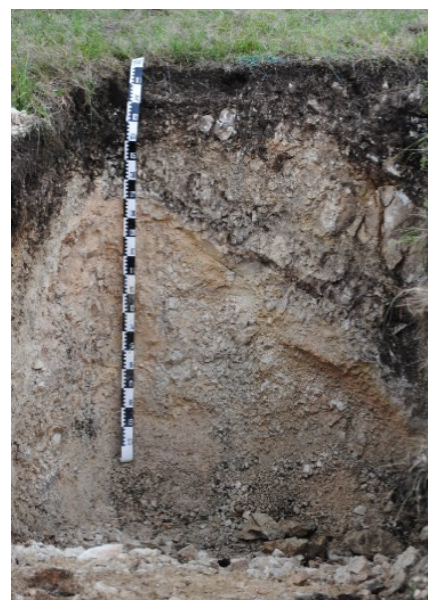

1. Ábra

Fekete rendzina talaj (Várpalota, Tési-fennsík) 
Kőzethatású talajok

A talajok besorolása nagyjából megegyezik az eddigiekkel. Ebben az esetben is érdemes lenne altípusként, vagy változatként a kőzet aprózódásának a mértékét is jelezni (Pl. sekélyen, mélyen felaprózódott). A besorolásnál problémát jelenthet a mozaikosság, hiszen egy-egy centiméter különbség már más típust eredményez. Az altípus meghatározásnál a hagyományos besorolás (rendzina/ranker/erubáz) helyett több információt adna az alapkőzet megadása (ez vonatkozik a sziklás-köves váztalajokra is). (1. ábra)

\section{Szolonyec - Szoloncsák talajok}

A két talajtípusnak eltérő a meghatározó bélyege, a kicserélhető kationok között a Na ${ }^{+} \%$-kos aránya, illetve az összes sótartalom. Talán érdemesebb lenne egységes bélyeget használni, és a sótartalom maximuma alapján elkülöníteni a két típust.

\section{Duzzadó agyatalajok}

A megadott definíciók egy része (agyagtartalom legalább 30\%) csak laboratóriumban, illetve a szelvény többszöri helyszíni megtekintésével (időszakosan nyíló és záródó repedések) határozható meg. Mindenképpen érdemes vizsgálni, hogy a hazai talajaink hány százaléka tartozna ebbe a típusba.

Réti talajok

A meghatározó bélyegek szigorúbbak a jelenlegi besorolásnál (talajfelszíntől $50 \mathrm{~cm}$-en belül az év egy részében reduktív viszonyok és $50-100 \mathrm{~cm}$ között talajvíz glej színmintázat). Ez elfogadható, de sok talajvíz hatású talaj „kiesik” a típusból.

\section{Karbonát talajok}

A definíció alapján (talajfelszíntől $50 \mathrm{~cm}$-en belül $\mathrm{CaCO}_{3}$-as szint (min. $25 \%$, legalább $15 \mathrm{~cm}$ vastag)) a hazai talajaink igen jelentős része ide fog tartozni. A hazai talajképző kőzetek esetén a $25 \%-o s \mathrm{CaCO}_{3}$ tartalmat gyakran elérik a lösz, a dunai öntések és a meszes homokon kialakuló talajok egy része. Egyes esetekben akár az erodált agyagbemosódásos barna erdőtalajok is ide sorolandók. Ennek megfelelően a hazai viszonyok között a típus definíciója átgondolandó.

\section{Mezőségi talajok}

A definíció alapján elsősorban a csernozjom talajok (föleg a mészlepedékes csernozjomok) tartoznak ide, kérdéses, hogy a humuszkarbonát talajok nem sorolódnak-e ki. További kérdés, hogy a múvelt mezőségi talajok esetén eléri-e a szervesanyag-tartalom a kívánt színt? (Ha nem ezek átkerülnek a barnaföldekhez.)

\section{Agyagbemosódásos barna erdőtalajok}

Nagyjából megfelel a jelenlegi agyagbemosódásos barna erdőtalajnak (talajfelszíntől $100 \mathrm{~cm}$-en belül agyagfelhalmozódási szint jelenik meg), esetleg ide tartoznak a pszeudoglejes barna erdőtalajok is, ha van bennük agyagbemosódás. Kérdés az agyagfelhalmozódási szint megjelenése megfelelően definiált-e? 


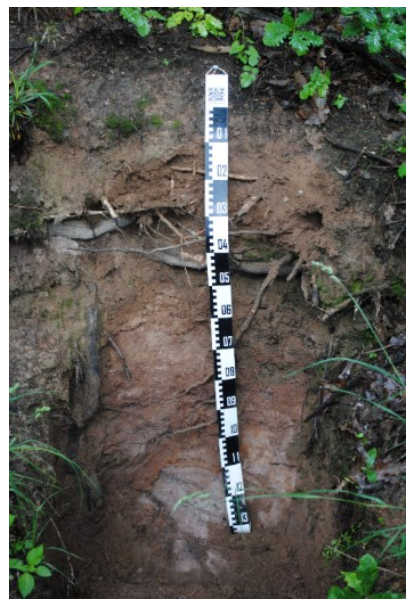

2. Ábra

Savanyú nem podzolos barna erdőtalaj homokkövön - Bakonya (Mecsek)

Homoktalajok

A definíció alapján (talajfelszíntől $100 \mathrm{~cm}$-en belül (vagy sekélyebben) a szövetük $\mathrm{DH}, \mathrm{H}$, vagy $\mathrm{VH}$ ) nagyon tág csoport - tisztán fizikai tulajdonságok alapján, futó homok, humuszos homok, kovárványos barna erdőtalaj, savanyú nem podzolos barna erdőtalaj is ide tartozhat. Terepen a fenti talajt (homokkövön kialakult savanyú nem podzolos barna erdőtalaj) is ide soroltuk. Ennek megfelelően nem túl szerencsés az elnevezés, vagy a definíciót kell módosítani. (2. ábra)

\section{Barnaföldek}

A jelenlegi barnaföldeknek megfelelő csoport, de a jelenlegi barnaföldek egy része már korábban kisorolt. Gondot okozhat az azonos név és az eltérő definíció, hiszen így nem tudhatjuk mit értünk a jövőben barnaföldek alatt.

\section{Hordaléktalajok}

A hordalék talajok nagy része már korábban kisorolt, pl. azért mert erősen meszes. A definíció megfelelő.

Földes kopárok névnek.

Egyéb talajok, amely meghatározás nem biztos, hogy megfelel a jelenlegi típus

Az egyes talajtípusok értékeléséböl látható, hogy az új rendszerben a talajok a maitól jelentősen eltérő típusba is kerülhetnek. Gondot okozhat az egyes típusok neve, hiszen az összekeverhető a jelenlegi névvel. Pl. a földes kopár típusnak jól meghatározott jelentése volt az elmúlt évtizedekben, most ez összekeverhető az új típussal. Ennek megfelelően javaslom, hogy az új rendszerbe új nevek kerüljenek megadásra. 


\section{Erdészeti alkalmazási lehetőség}

Bár a munkának - tudomásom szerint - nem volt és talán nem is lehetett célja, hogy az erdészeti termőhelyosztályozási rendszerhez illeszkedjen, úgy vélem, hogy az erdész szakma számára alapvető fontosságú ennek a kérdésnek a vizsgálata a további alkalmazás szempontjából.

A ma alkalmazott hazai erdészeti termőhelyosztályozási rendszer a múlt század ötvenes-hatvanas éveiben alakult ki (BABOS et. al. 1966, JÁRó 1963). Bár a rendszer azóta több változáson esett át, lényege nem változott. A rendszer létrehozásának és alkalmazásnak célja az egyes területeken a fafaj választás megalapozása, illetve az erdőművelési és erdőhasználati eljárások - termőhely függő - elvégzése. Ennek megfelelően a rendszer elsődlegesen a gyakorlati igényeket kívánja kielégíteni, és kevésbé a tudományos, illetve a nemzetközi megfelelőség a cél.

\section{A jelenlegi erdészeti adatok használhatósága}

Ma hazánk területének közel 21 \%-át erdő alkotja. Az erdőterületek adatait egységes szerkezetben az Országos Erdőállomány Adattár (továbbiakban adattár) tartalmazza. Az adattár a terület (pl. községhatár, részlet nagysága) és az erdőállomány jellemzői (pl. fafaj, kor, fatömeg, magasság, átmérő, elegyarány) mellett, minden részletre (ez általában 1-20 ha-os terület) termőhelyi adatokat is tartalmaz. A termőhelyi adatok közül a klíma, a hidrológiai viszonyok és a talajra vonatkozó adatok mellett, szerepel még a domborzatra, a fekvésre és a tengerszint feletti magasságra vonatkozó adat is. A talajadatok közül a genetikai talajtípus, a termőréteg vastagsága és a fizikai féleség szerepel az adattárban. Az új osztályozási javaslat alkalmazása szempontjából az a kérdés, hogy át lehet-e fordítani az adattárban megadott talajadatokat a javasolt rendszerbe. A javaslat 15 talajtípust tartalmaz, amelyeket altípusok és változatok egészítenek ki. Sajnos a „régi” talajtípusok nem feleltethetők meg egyértelmüen - különösen részletes talajleírás nélkül - az új rendszer talajtípusainak, ami azt jelenti, hogy a jelenlegi adatbázis adatai a javaslat bevezetése esetén a jövöben korlátozottan lesznek használhatók. Véleményem szerint ez a javaslat bevezetésének egyik igen nagy korlátját jelenti.

\section{Fafaj választás}

Az erdészeti termőhelyosztályozás kiemelt célja az egyes területeken ültehető fafajok megadása. Ez a jelenlegi rendszerben a termőhelytípus változatok (klimatikus körülmények (Bükkös - B, Gyertyános-tölgyes - GYT, Csereskocsánytalan tölgyes - CS-KTT és Erdőssztyepp - ESZTYP klíma), a hidrológiai viszonyok, a genetikai talajtípus, a termőréteg vastagsága és a fizikai féleség) alapján történik. Az egyes termőhelytípus változatokhoz fafajokat rendeltek hozzá és megadták ezek potenciális növekedését. Az új rendszerben több genetikai talajtípus is ugyanazon talajtípusba kerülhet, ezért azt vizsgáltuk, hogy ebben az 
esetben azonosak-e a válaszható fafajok. A következőkben három példát szeretnénk bemutatni.

A homoktalajok közé kerülnek a jövőben a futóhomokok és a humuszos homoktalajok (MICHÉLI et. al. 2015). Ezen talajokon alkalmazható fafajokat az 1. táblázat tartalmazza.

\section{1. táblázat}

Futóhomokok $(\mathrm{FH})$ és a humuszos homok $(\mathrm{HH})$ talajokon alkalmazható fafajok és növekedésük

\begin{tabular}{|c|c|c|c|c|c|}
\hline \multirow[t]{2}{*}{$\begin{array}{l}\text { Genetikai } \\
\text { talajtípus }\end{array}$} & \multirow[t]{2}{*}{$\begin{array}{l}\text { Termőréteg } \\
\text { vastagság }\end{array}$} & \multirow[t]{2}{*}{$\begin{array}{l}\text { Fizikai } \\
\text { féleség }\end{array}$} & \multicolumn{3}{|c|}{$\begin{array}{c}\text { Alkalmazható fafaj és annak növekedése az } \\
\text { adott klímában }\end{array}$} \\
\hline & & & GYT & CS-KTT & ESZTYP \\
\hline $\mathrm{FH}$ & ISE & $\mathrm{DH}$ & & & FRNY gy, FF gy \\
\hline $\mathrm{HH}$ & ISE & DH & & & $\begin{array}{l}\text { FRNY gy, A gy, } \\
\text { FF gy }\end{array}$ \\
\hline $\mathrm{FH}$ & ISE & $\mathrm{H}$ & & & FRNY gy, FF gy \\
\hline $\mathrm{HH}$ & ISE & $\mathrm{H}$ & $\begin{array}{l}\text { FRNY gy-k, } \\
\text { EF gy-k }\end{array}$ & $\begin{array}{l}\text { FRNY } \\
\text { gy, FF gy }\end{array}$ & $\begin{array}{l}\text { FRNY gy, A gy, } \\
\text { FF gy }\end{array}$ \\
\hline $\mathrm{FH}$ & $\mathrm{SE}$ & DH & & & $\begin{array}{l}\text { FRNY gy, A gy, } \\
\text { FF gy }\end{array}$ \\
\hline $\mathrm{HH}$ & SE & DH & & & $\begin{array}{l}\text { FRNY gy, A gy, } \\
\text { EF gy-k, FF k }\end{array}$ \\
\hline $\mathrm{FH}$ & $\mathrm{SE}$ & $\mathrm{H}$ & & & $\begin{array}{l}\text { FRNY gy, A gy, } \\
\text { FF gy }\end{array}$ \\
\hline $\mathrm{HH}$ & $\mathrm{SE}$ & $\mathrm{H}$ & $\begin{array}{l}\text { CS gy-k, } \\
\text { FRNY gy-k, A } \\
\text { gy-k, EF k }\end{array}$ & $\begin{array}{l}\text { CS gy-k, } \\
\text { FRNY k, } \\
\text { A k, EF k }\end{array}$ & $\begin{array}{l}\text { FRNY gy, A gy, } \\
\text { EF gy-k, FF k }\end{array}$ \\
\hline
\end{tabular}

Jelmagyarázat: A-akác, EF-erdei fenyő, FRNY-fehér nyár, FF- fekete fenyő Növekedés: j-jó, k-közepes, gy-gyenge

A jövőben a rendzina, az erubáz és a ranker talajok azonos talajtípusba a kőzethatású talajok típusába kerülnének (MICHÉLI et. al. 2015). A 2. táblázatban az vizsgáltuk, hogy azonos-e ezen talajtípusokon az alkalmazható fafajok köre. 
2. táblázat

Rendzina (RE), erubáz (ER) és ranker (RA) talajokon alkalmazható fafajok és növekedésük

\begin{tabular}{|c|c|c|c|c|c|}
\hline \multirow[t]{2}{*}{$\begin{array}{l}\text { Genetikai } \\
\text { talajtípus }\end{array}$} & \multirow[t]{2}{*}{$\begin{array}{c}\text { Termőréteg } \\
\text { vastagság }\end{array}$} & \multirow[t]{2}{*}{$\begin{array}{l}\text { Fizikai } \\
\text { féleség }\end{array}$} & \multicolumn{3}{|c|}{$\begin{array}{l}\text { Alkalmazható fafaj és annak növekedése az adott } \\
\text { klímában }\end{array}$} \\
\hline & & & GYT & CS-KTT & ESZTYP \\
\hline ER & ISE & A & & $\begin{array}{l}\text { KTT gy, MOT gy, CS } \\
\text { gy, FF gy-k, EF gy-k }\end{array}$ & $\begin{array}{l}\text { KTT gy, MOT gy, CS gy, } \\
\text { EF gy-k, FF gy-k }\end{array}$ \\
\hline RA & ISE & A & & $\begin{array}{l}\text { KTT gy, CS gy-k, EF } \\
\text { gy-k }\end{array}$ & \\
\hline $\mathrm{RE}$ & ISE & A & & MOT gy, CS gy & MOT gy, CS gy \\
\hline ER & ISE & $\mathrm{V}$ & & $\begin{array}{l}\text { KTT gy, MOT gy, CS } \\
\text { gy, FF gy-k, EF gy-k }\end{array}$ & $\begin{array}{l}\text { KTT gy, MOT gy, CS gy, } \\
\text { EF gy-k, FF gy-k }\end{array}$ \\
\hline RA & ISE & $\mathrm{V}$ & & $\begin{array}{l}\text { KTT gy, CS gy-k, EF } \\
\text { gy-k }\end{array}$ & \\
\hline RE & ISE & $\mathrm{V}$ & & $\begin{array}{l}\text { MOT gy, CS gy, VK } \\
\text { gy, FF gy-k }\end{array}$ & $\begin{array}{l}\text { MOT gy, CS gy, VK gy, } \\
\text { FF gy-k }\end{array}$ \\
\hline
\end{tabular}

Jelmagyarázat: A-akác, CS-cser, H-hárs, EF-erdei fenyő, KTT-kocsánytalan tölgy, KSTkocsányos tölgy, VT-vöröstölgy, FRNY-fehér nyár, EH-ezüst hárs, FF - fekete fenyő

Növekedés: j-jó, k-közepes, gy-gyenge

3. táblázat

Agyagbemosódásos barna erdőtalaj (ABE) és podzolos barna erdőtalaj (PBE) talajokon alkalmazható fafajok és növekedésük

\begin{tabular}{|c|c|c|c|c|c|}
\hline \multirow[t]{2}{*}{$\begin{array}{l}\text { Genetikai } \\
\text { talajtípus }\end{array}$} & \multirow[t]{2}{*}{$\begin{array}{c}\text { Termőréteg } \\
\text { vastagság }\end{array}$} & \multirow[t]{2}{*}{$\begin{array}{l}\text { Fizikai } \\
\text { féleség }\end{array}$} & \multicolumn{3}{|c|}{$\begin{array}{c}\text { Alkalmazható fafaj és annak növekedése az adott } \\
\text { klímában }\end{array}$} \\
\hline & & & B & GYT & CS-KTT \\
\hline $\mathrm{ABE}$ & IMÉ & $\mathrm{V}$ & $\begin{array}{l}B \mathrm{j}, \mathrm{LF} \mathrm{j}, \mathrm{DF} \mathrm{j}, \\
\mathrm{JF} \mathrm{j}\end{array}$ & $\begin{array}{l}\text { KTT j, LF j, } \\
\text { DF j }\end{array}$ & \\
\hline PBE & IMÉ & $\mathrm{V}$ & $\mathrm{B} \mathrm{j}, \mathrm{LF} \mathrm{j}$ & $\begin{array}{l}\text { KTT j, LF j } \\
\text { DF j }\end{array}$ & \\
\hline $\mathrm{ABE}$ & KMÉ & $\mathrm{V}$ & $\mathrm{B} \mathrm{k}, \mathrm{LF} \mathrm{j}$ & $\begin{array}{l}\text { KTT k, VT j } \\
\text { CS j }\end{array}$ & \\
\hline PBE & KMÉ & $\mathrm{V}$ & $\mathrm{B} \mathrm{k}, \mathrm{EF} \mathrm{k}$ & KTT k, EF k & $\begin{array}{l}\text { KTT gy-k, CS k } \\
\text { EF k }\end{array}$ \\
\hline $\mathrm{ABE}$ & MÉ & $\mathrm{V}$ & $\begin{array}{l}\text { B j, LF j, DF j } \\
\text { JF j }\end{array}$ & $\begin{array}{l}\text { KTT j, LF j, } \\
\text { DF j }\end{array}$ & \\
\hline PBE & MÉ & $\mathrm{V}$ & $\mathrm{B} \mathrm{j}, \mathrm{LF} \mathrm{j}$ & $\begin{array}{l}\text { KTT j, LF j } \\
\text { DF j }\end{array}$ & \\
\hline
\end{tabular}

Jelmagyarázat: A-akác, CS-cser, H-hárs, EF-erdei fenyő, KTT-kocsánytalan tölgy, KSTkocsányos tölgy, VT-vöröstölgy, FRNY-fehér nyár, EH-ezüst hárs, FF - fekete fenyő, Jjuhar, MK- magas kőris

Növekedés: j-jó, k-közepes, gy-gyenge 
Az agyagbemosódásos talajok típusába fog tartozni az agyagbemosódásos barna erdőtalaj és a podzolos barna erdőtalaj (MICHÉLI et. al. 2015), ezek esetében is vizsgáltuk az alkalmazható fafajokat és azok növekedését. (3. táblázat)

A táblázatok alapján néhány megállapítást tehetünk. Az új talajtípusokba erdészeti szempontból - igen eltérö termőképességü „régi” talajtípusok kerültek be. A különbség az egyes klimatikus adottságok esetén eltérő lehet, hiszen a fafaj választást a termőhelyi tényezők összessége határozza meg. Az „új osztályozásban” létrejövő talajtípusok - a típuson belüli nagy változatosság miatt - a legtöbb esetben nem alkalmasak a fafaj választás megalapozásához. Ha az erdészeti termőhely osztályozás át akar térni a diagnosztikai elveken nyugvó talajosztályozásra - új rendszert kell kidolgozni, illetve altípusok és változatok szintjén kell meghatároznunk a fafaj javaslatot.

\section{Hogyan tovább?}

Egy talajosztályozási rendszernek igen sokféle célnak kell megfelelnie. Szükséges, hogy a talajokról szerzett ismereteket rendszerezze. A talajokban lejátszódó folyamatokat és ezek összefüggéseit mutassa be, adjon információ a talajhasználók, a döntéshozók és a társadalom számára, tegye lehetővé talajadatbázisok létrehozását. Ugyanakkor speciális igények is megjelenhetnek egy osztályozási rendszerrel szemben, így segítsen meghatározni a talaj termékenységét, az adott talajon segítse a fafaj választás megalapozását és a fafajok növekedésének elöre becslését. Nem tudom, hogy van-e olyan osztályozási rendszer, ami mindezen céloknak megfelel.

Az új osztályozási rendszer a hazai talajosztályozás számára számtalan elöre vivő javaslatot tartalmaz, a felhozott kritikák ellenére. Ennek megfelelően érdemes lenne a szerzők által kijelölt úton tovább haladni. Ezt, jelen vélemény írója a következőkben tudja elképzelni:

- Egységes, pontos definíciókon alapuló hazai talajleíró rendszer kidolgozása és alkalmazása. (Érdemes lenne a TIM pontok újrafelvételéig ezen rendszert elkészíteni és az újrafelvétel során kipróbálni.)

- Ezen talajleírásokat egységes adatbázisban kellene tárolni.

- A leírások alapján pontosítani lehetne a jelenlegi talajtípusok definícióit, illetve az egyes pontokat be kellene sorolni a ,hagyományos”, a WRB és a megújított rendszer alapján. Ezen adatokat is egységes adatbázisban kellene tárolni.

- Néhány mintatérképet kellene készíteni az egyes osztályozási elvek szerint. Mit és hogyan tudunk térképen ábrázolni? Mennyire felelnek meg a gyakorlat igényeinek az ilyen térképek?

- Néhány ezer megfelelően leírt és besorolt talajszelvény után ki kellene értékelni az egyes rendszerek előnyeit és hátrányait.

- Az értékelés alapján lehetne egy új osztályozási rendszert létrehozni. 


\section{Irodalom}

Állami ERdészeti SzOlgÁlat (ÁESZ), (2004). Erdészeti Szakigazgatási Információs Rendszerhez kapcsolódó Erdőtervezési Útmutató Kódjegyzék és mellékletei. ÁESZ. Budapest.

Babos I. Horváthné Proszt S., JÁró Z. KirÁly L., SzOdFridT I., Tóth B., (1966). Erdészeti termőhelyfeltárás és térképezés. Akadémiai Kiadó. Budapest.

DöVÉNYI Z., (szerk.) (2010). Magyarország kistájainak katasztere, MTA Földrajztudományi Kutatóintézet. Budapest.

JÁRÓ Z., (1963) Talajtípusok, Országos Erdészeti Főigazgatóság. Budapest.

Michéli E., Fuchs M., LÁNG V., SZEGi T., Dobos E., SZABónÉ Kele G., (2015): Javaslat talajosztályozási rendszerünk megújítására: alapelvek, módszerek, alapegységek. Agrokémia és talajtan. 64. (1) 285-297.

Michéli E., FuChS M., SZEgi T., CSORBA Á., Dobos E., SZABÓné Kele G., (2018). A diagnosztikus szemléletben megújított hazai talajosztályozási rendszer. Alapelvek, felépítés, osztályozási szabályok. Vitaanyag 2018.10.10. SZIE. Gödöllö. http://talaj.hu/wpcontent/uploads/2019/04/Hazai talajosztalyozasi rendszerunk megujitasi javaslatai 20181010.pdf

StefanOVITS P., FiLeP G., FÜLeKY G., (1999). Talajtan. Mezőgazda Kiadó. Budapest.

Open Access nyilatkozat: A cikk a Creative Commons Attribution 4.0 International License (https://creativecommons.org/licenses/by/4.0) feltételei szerint publikált Open Access közlemény, melynek szellemében a cikk bármilyen médiumban szabadon felhasználható, megosztható és újraközölhető, feltéve, hogy az eredeti szerző és a közlés helye, illetve a CC License linkje és az esetlegesen végrehajtott módosítások feltüntetésre kerülnek. (SID_1) 